\title{
High-Resolution Sub-Bottom and Magnetometer Data From Southeastern Brazilian Coast
}

\author{
Daniel Pavani Vicente Alves ${ }^{1 *}$, Eduardo Bomfin Caldato ${ }^{2}$, Denise Silva de Moura ${ }^{3}$, \\ Roberto P. Zanon dos Santos ${ }^{3}$ and Luigi Jovane ${ }^{1}$ \\ 1 Department of Physical, Chemical and Geological Oceanography, Institute Oceanographic, Universidade de São Paulo, \\ São Paulo, Brazil, ${ }^{2}$ Department of Natural Resources and Hydrogeology, Institute of Geosciences, Universidade de \\ São Paulo, São Paulo, Brazil, ${ }^{3}$ Department of Geophysics, Institute of Astronomy, Geophysics and Atmospheric Sciences, \\ São Paulo, Brazil
}

Keywords: reflection seismic, magnetic anomalies, geophysics, oceanography, geologic oceanography

\section{INTRODUCTION}

Sub-bottom profilers are used across shallow and deep oceanic waters with several applications, such as sea-level studies (e.g., Bastos et al., 2010; Koša, 2015; Aquino da Silva et al., 2016; Yoo et al., 2016), sedimentation process (e.g., Miller et al., 2013; Alves and de Mahiques, 2019), gas seeps (e.g., Benites et al., 2015; Michel et al., 2017), geomorphology (e.g., Jobe et al., 2011; Gomes et al., 2016), and others. Marine magnetometer data have also been used for most various studies,

OPEN ACCESS

Edited by:

Vincent Lecours,

University of Florida, United States

Reviewed by:

Y. Meriah Arias-thode

Naval Information Warfare Center

Pacific, United States

Daniele Maestrelli,

National Research Council, Italy

*Correspondence:

Daniel Pavani Vicente Alves

daniel.alves@usp.br

Specialty section:

This article was submitted to

Deep-Sea Environments and Ecology,

a section of the journal

Frontiers in Marine Science

Received: 13 March 2020

Accepted: 28 August 2020

Published: 16 October 2020

Citation:

Alves DPV, Caldato EB, de Moura DS, dos Santos RPZ and Jovane L (2020)

High-Resolution Sub-Bottom and Magnetometer Data From

Southeastern Brazilian Coast.

Front. Mar. Sci. 7:536295.

doi: 10.3389/fmars.2020.536295 as archeological (Boyce et al., 2004), environmental (Boyce et al., 2001), engineering (Yu et al., 2007), and geological, mainly for mineral exploration (Dehler and Potter, 2002) and academic purposes (Müller et al., 1997). Combining both techniques enhances considerably the possibilities of geological and oceanographic interpretation, as multi-data surveys in marine environments allow complementary studies (e.g., Kadima et al., 2011; Demir et al., 2012).

The Boqueirão Strait in the northern coast of São Paulo (Southeast Brazil) connects two semi-enclosed bays, allowing water exchange between them (Mahiques and Souza, 1999). Despite its importance to the oceanographic evolution of the region, it has still been poorly studied. Therefore, this new dataset will contribute to future comprehension of the geologic and oceanographic evolution.

\section{DATA COLLECTION}

\section{Location and Date}

New seismic and magnetometer data were acquired on the region of the Boqueirão Strait during a cruise between November 26 and 30, 2018, onboard R/V Veliger II from Instituto Oceanográfico of Universidade de São Paulo. This 35-m-deep strait is located between $23^{\circ} 31^{\prime} \mathrm{S} / 45^{\circ} 06^{\prime} \mathrm{W}$ and $23^{\circ} 32^{\prime} \mathrm{S} / 45^{\circ} 04^{\prime} \mathrm{W}$ and is a unique region that separates the shallow areas of Flamengo Bay and the Toninhas Bay on the city of Ubatuba, northern coast of São Paulo State, Brazil (Figure 1). The strait also separates the continent from the Anchieta Island, a touristic destiny whose main beaches are located on Palmas Bay (Figure 1). The strait was probably formed from an ancient drainage system developed during the Quaternary in the Brazilian coast (Almeida, 1964), and, in fact, Mahiques and Souza (1999) found seismic and sediment evidences of regressive and transgressive surfaces in the area.

The Ubatuba region is characterized by the proximity of the Serra do Mar from the shore (Figure 1). The input of terrigenous sediments into the bay is mostly controlled by rainfall, resulting in fine sediments rich in organic matter (Mahiques, 1995). Sediments reaching the Flamengo Bay are characterized by a clockwise transport system. These sediments are reworked by the water that enters the bay from the western sector (Mahiques and Souza, 1999). On the Boqueirão area, 
circulation is mostly due to SW-NE wind and wave currents that, with appropriate cold fronts influence, can reach up to $0.80 \mathrm{~m} / \mathrm{s}$ (Tessler, 1988; Mahiques and Souza, 1999).

\section{Seismic Data Collection}

High-resolution single-channel seismic data were acquired using a SIG Sparker ELC-1200L coupled to an Energos 300J power supply, operating at 250J with a signature source-frequency of $0.9 \mathrm{kHz}$ and $3.4 \mathrm{~ms}$ vertical resolution. Acquisition was performed at a constant vessel speed of 3.5 knots and, for decreasing the effect of vessel noise, the source used a 25$\mathrm{m}$ layback. For data recording, a 4.7-m length SIG Streamer was used, with a single-channel formed by eight hydrophones coupled to a pre-amplifier to increase signal-noise rate. In order to minimize the effect of the vessel's noise on the hydrophones, the streamer used a 35-m layback, therefore spaced $10 \mathrm{~m}$ from the seismic source. Both the layback lengths for source and streamer were defined after a testing and calibration period prior to acquisition, in which different lengths were applied and noise decrease was read in the online data view of the acquisition software. More than $30 \mathrm{~km}$ of seismic data were collected in the datum WGS84 and UTM $23 \mathrm{~S}$ projection, in a total coverage of circa $1.6 \mathrm{~km}^{2}$ (Figure 1).

The acquisition of seismic data was performed with the software Meridata MDCS 5.2, which controlled shot and recording settings. The source used a SEG capacitor bank of up to $300 \mathrm{~J}$, which was triggered by MDCS software. Navigation was acquired with a DGPS system Hemisphere Atlas Link, which provides horizontal resolution up to $0.1 \mathrm{~m}$ and vertical precision of $0.2 \mathrm{~m}$. Installation offsets were measured on the port.

\section{Magnetometer Data Collection}

A magnetometric survey was performed using a SeaSPY 2 magnetometer, from Marine Magnetics, simultaneous to the seismic survey. The SeaSPY has an Overhauser sensor that measures the intensity of the magnetic field vector, regardless of its direction. The resolution is $0.001 \mathrm{nT}$ and the absolute accuracy is $0.1 \mathrm{nT}$. There is no heading error, temperature drift, or dead zone associated with the measurements.

The magnetometer layback was $30 \mathrm{~m}$ to avoid interferences from the vessel, along the same profiles presented in Figure 1, adding the maneuver path. The optimal tow-cable length has been defined to be $30 \mathrm{~m}$ after several surveys with the research vessel. Prior to acquisition, offsets for the magnetometer and GPS antenna were measured and applied to the acquisition software BOB. The sample rate was $1 \mathrm{~Hz}$, resulting in 13,330 data points distant by $4 \mathrm{~m}$ along the profiles.

The diurnal magnetic anomaly was registered by a ground Overhauser magnetometer, a GSM-19 from GEM Systems, located at a shore-based magnetic station, on the Ubatuba base of the Instituto Oceanográfico of Universidade de São Paulo, $5 \mathrm{~km}$ apart from the survey area.

\section{DATA DESCRIPTION}

\section{Seismic Dataset}

After acquisition, seismic data were converted to SGY format (IEEE Float-32 bit) using Meridata REX software and applying the acquisition offsets. Therefore, all seismic data have precise position information (bytes 73 and 77) in WGS84/UTM 23S. Shotpoint (SP) information is located on byte 17. No filters, gain, or any other processing was applied to the data, except for the pre-amplifier on the streamer. Trace length varies between 100 and $150 \mathrm{~ms}$, with sampling interval of $50 \mu \mathrm{s}$ and positive seabed reflection. Details on the seismic data format are presented on Table 1.

Given the proximity of the Serra do Mar formation to the coast in this region, it is possible to interpret the acoustic basement (interpreted in red in Figures 2A,B) as the crystalline basement in most of the seismic sections. A detailed view of the survey area shows the basement outcrops near the continent (north) and the Anchieta Island (south). A seismic line $\mathrm{N}-\mathrm{S}$ oriented (Figure 2A) indicates that the basement is much shallower in the southern sector, close to the Anchieta Island, and some sections clearly show the basement outcropping on the seafloor (Figure 2B), pointing to the connection between the continent and the island.

Above the basement reflector and the present seafloor multiple (mapped in green in Figure 2A), it is possible to notice important reflectors related to ancient oceanographic and possibly sea-level conditions. The "paleo-Boqueirão" represents an ancient configuration of the region, with morphological characteristics much similar to the present. On the flanks of this paleo-depression, a stabilization surface on the northern sector and a ravinement surface on the southern, as well as erosive truncation on the slope, point to structures produced by sea-level variations, as interpreted by Mahiques and Souza (1999).

\section{Magnetometer Dataset}

The abnormal spikes were removed from the collected dataset; thereafter, the diurnal magnetic correction was applied using shore-based magnetic station data. Besides the preprocessing described above, no filter or further corrections were applied to calculate the total magnetic field (Figure 2C). A NE trending formed by a series of dipoles is highlighted by the magnetic data. The pattern can be related to the basement structure, since the region is located in the Ribeira Belt, a neoproterozoic orogenic belt formed by the accretion of terranes in the NE trending (Heilbron and Machado, 2003).

\section{Data Availability}

The seismic and magnetometer data are available in the community at FigShare.com (doi: 10.6084/m9.figshare. 11861889). Seismic data are available in SGY format (see detailed description in Table 1). SGY files are named following their date: YYYYMMDD_HHMMSS. Magnetometer data are 


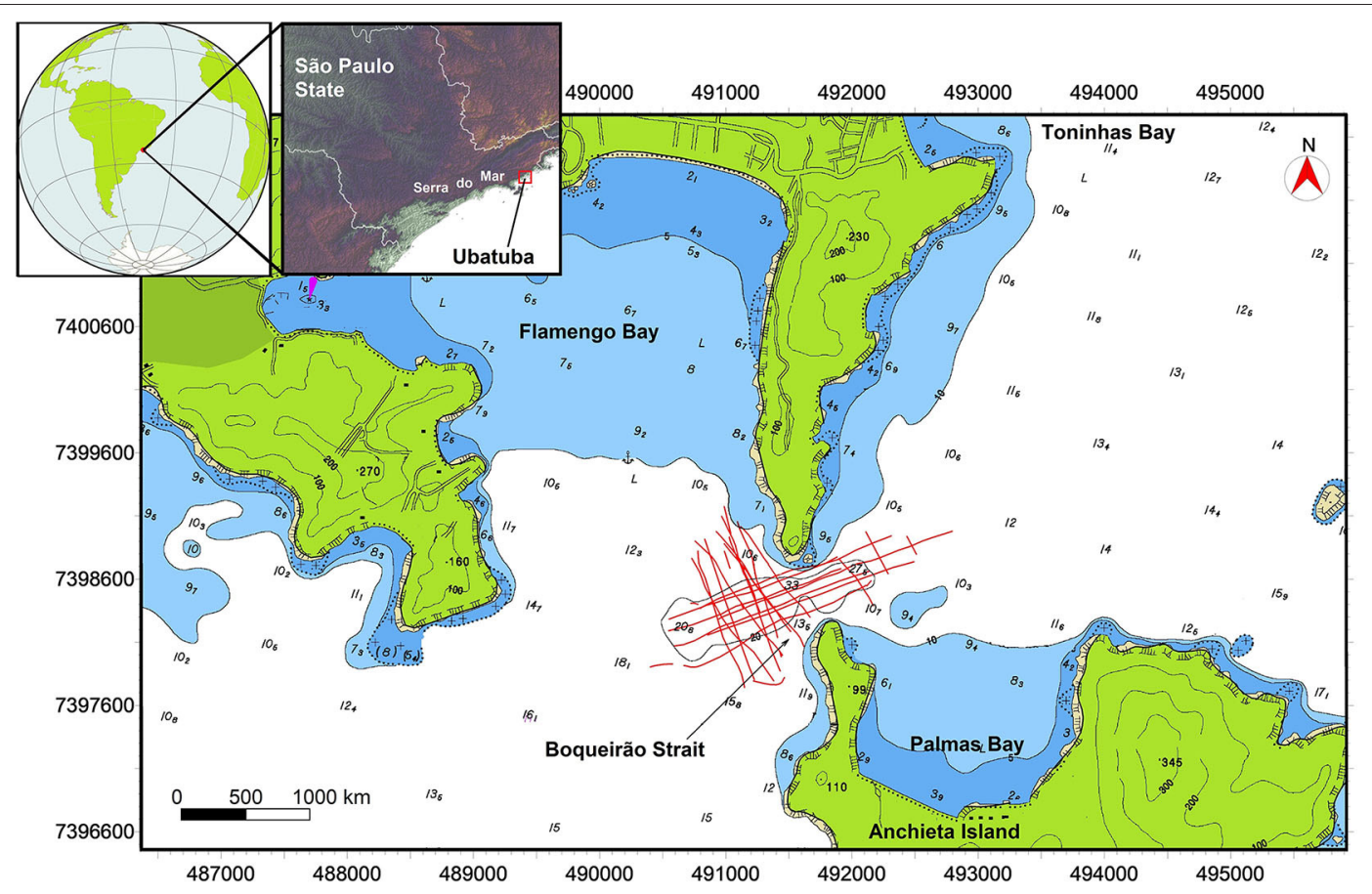

FIGURE 1 | The data were acquired in the Southeastern Brazilian coast, on the north coast of São Paulo state. The seismic and magnetometer acquisitions (red lines) were acquired in the Boqueirão Strait, a narrow passage between the continent and the Anchieta Island. Top left box shows USGS SRTM topography and the position of Serra do Mar (warmer colors represent higher altitudes).

TABLE 1 | Summary of SGY data information.

\begin{tabular}{ll}
\hline Name format & DATE_TIME.sgy \\
Data format & SGY IEEE Float (32 bit) \\
Position & WGS84/UTM 23S \\
Gain & No \\
Filter & No \\
Pre-amplify & Applied on the streamer \\
Bytes for XY information & $73 / 77$ \\
Byte for SP information & 17 \\
Trace length & $100-150$ ms \\
Sample interval & $50 \mu s$ \\
Seafloor reflection & Positive
\end{tabular}

available on text file format (.XYZ), including navigation. Data also include the shapefile of the seismic acquisition survey.

\section{POSSIBLE APPLICATIONS}

Mahiques and Souza (1999) published the seismic stratigraphy of the Boqueirão Strait two decades ago. With the technological advances in seismic acquisition, these new data provide a better tool to enhance the studies on the region. The improvement of data is based on positioning technology evolution, with the use of differential Global Positioning System (GPS), for example, as well as newer seismic source, recorder, and digital/analogic conversion tools. The seismic and paleobathymetry characteristics of this strait can provide important information to the Quaternary evolution of the southern coast of Brazil. With the support of other data such as cores and gravimetric data, more detailed research can be carried out in order to contribute to the still poor sea-level change studies on the region (Klein et al., 2005; Veiga, 2005; Angulo et al., 2006; Alves and de Mahiques, 2019).

This dataset can be used as a guide for sediment sampling. Recent studies question the actual sea-level curve applied to portions of São Paulo coast (Suguio and Martin, 1978; Angulo et al., 2006). Sediment cores would make it possible to date and correlate the seismic surfaces interpreted with sea-level changes during the Quaternary.

For studies focused on tectonics of passive margins, these datasets are oriented to guide data acquisitions in a more regional perspective. Many of the faults found on the seismic data show the same orientation observed on continental outcrops. Authors such as Almeida (1964) and Zalán and Oliveira (2005) offer a different perspective over the evolution of the rift systems found southeast of Brazil. Nonetheless, the lack of information over the continental shelf creates a gap of data between continental and deep marine deposits. This dataset was a first attempt to search for structures that relate tectonics with syndepositional sedimentation. 


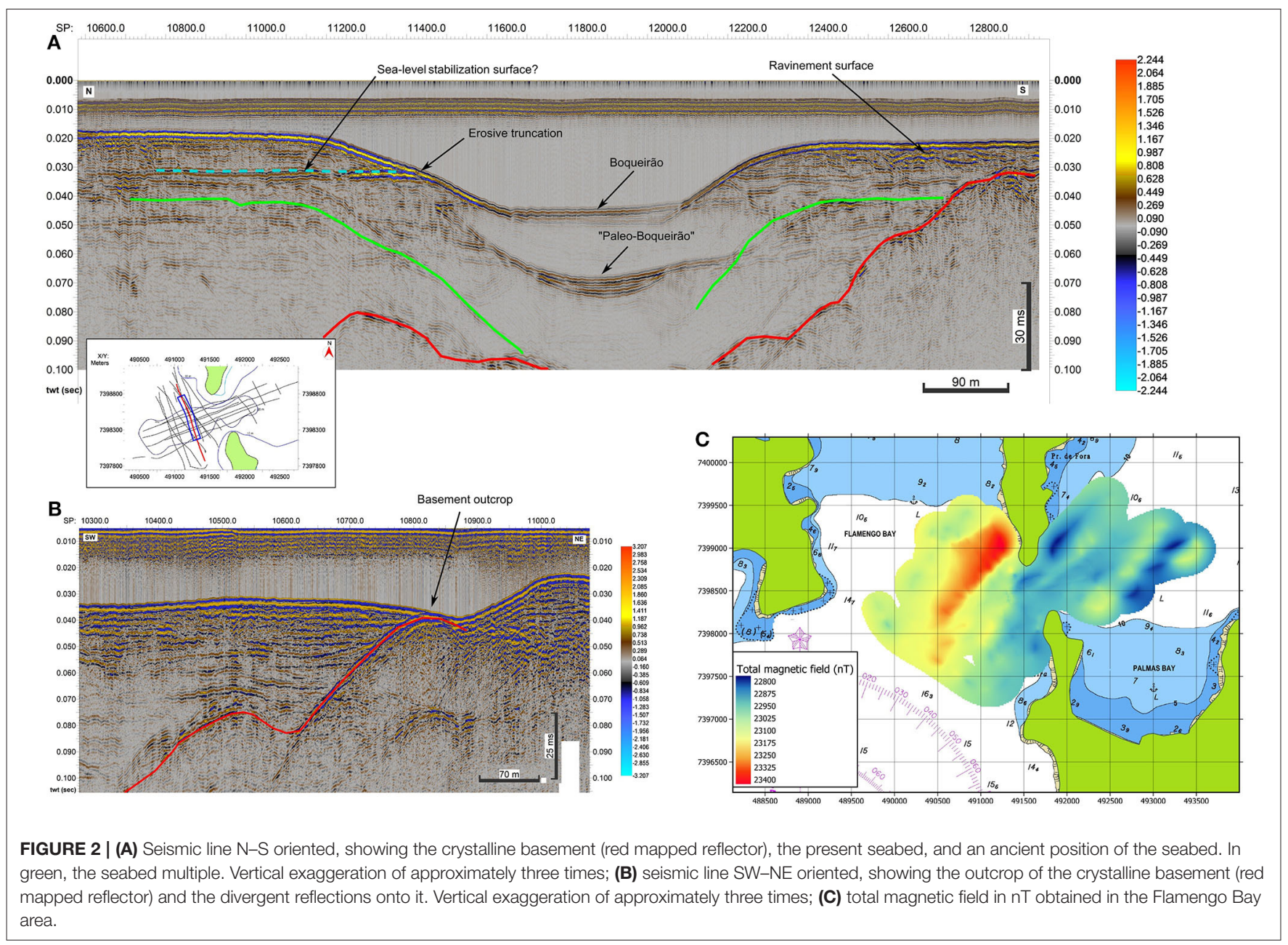

The magnetic data can be used to distinguish geological structures on the area, as faults and basement features that may complement studies about the formation of the bay, identifying fragile zones and regional patterns.

\section{Limitations}

The limitation of this single-channel seismic data is related to the acquisition process in shallow water environments. In such environment and in addition to using a single-channel system, the multiple reflections are present and the removal is difficult (Figure 2A). Additionally, as a high-energy source $(250 \mathrm{~J})$ was used in order to reach the deepest areas of the basement, the shallowest regions have high-amplitude reflections and multiples.

Recording was maintained even during short crossing lines and owing to that, some seismic lines are very short. Nevertheless, all lines were kept in the dataset.

Finally, the most important limitation is that there are no new sediment cores in the area. Therefore, with this dataset alone, it is not possible to assign sedimentary information and/or ages to the reflectors.
The uncompleted magnetic anomalies limit the interpretation of the volume and depth of the magnetic sources. Since the anomalies are not completely outlined, the modeling of them is not conclusive.

\section{FINAL REMARKS}

The north coast of São Paulo state in Southeastern Brazil is a region of great importance due to its natural conservancy and environmental significance. It is fundamental to further develop studies in the regions, especially those related to its formation and evolution of this portion of the Brazilian Margin. Only with this information the scientific community will be able to provide evolution models for the area, better understanding the effects of sea-level and depositional changes during the Quaternary and Holocene. These kinds of studies will contribute to the development of climate change scenarios for coastal zones and aid government mitigatory policies. Therefore, this new geophysical dataset can aid researchers with those goals. 


\section{DATA AVAILABILITY STATEMENT}

The datasets generated for this study are available on request to the corresponding author and also available at FigShare.com (doi: 10.6084/m9.figshare.11861889).

\section{AUTHOR CONTRIBUTIONS}

DA, EC, and DM were responsible for data collection and organization. DA was responsible for writing the manuscript. EC, $\mathrm{DM}$, and RS were responsible for reviewing the manuscript. LJ coordinated the process. All authors contributed to the article and approved the submitted version.

\section{REFERENCES}

Almeida, F. F. M. (1964). "Os fundamentos geológicos do relevo paulista," in Brasil, a terra e o homem (São Paulo: Companhia Editora Nacional), 55-120.

Alves, D. P. V., and de Mahiques, M. M. (2019). Deposition and sealevel evolution models for Upper Pleistocene/Holocene in the São Sebastião Channel (SE Brazilian coast) inferred from 5th order seismic stratigraphy. J. South Am. Earth Sci. 93, 382-393. doi: 10.1016/j.jsames.2019. 05.012

Angulo, R. J., Lessa, G. C., and De Souza, M. C. (2006). A critical review of mid- to late-Holocene sea-level fluctuations on the eastern Brazilian coastline. Quat. Sci. Rev. 25, 486-506. doi: 10.1016/j.quascirev.2005. 03.008

Aquino da Silva, A. G., Stattegger, K., Schwarzer, K., Vital, H., Aquino da Silva, A. G. A. G., Stattegger, K., et al. (2016). Seismic stratigraphy as indicator of late Pleistocene and Holocene sea level changes on the NE Brazilian continental shelf. J. South Am. Earth Sci. 70, 188-197. doi: 10.1016/j.jsames.2016. 05.001

Bastos, A. C., Vilela, C. G., Quaresma, V. S., and Almeida, F. K. (2010). Mid- to late-Holocene estuarine infilling processes studied by radiocarbon dates, high resolution seismic and biofacies at Vitoria Bay, Espirito Santo, Southeastern Brazil. An. Acad. Bras. Cienc. 82, 761-770. doi: 10.1590/S0001-376520100003 00022

Benites, M., Alves, D. P. V., de los Santos Maly, M., Jovane, L., Maly, M., de los, S., et al. (2015). Shallow gas occurrence in a Brazilian ría (Saco do Mamanguá, Rio de Janeiro) inferred from high-resolution seismic data. Cont. Shelf Res. 108, 89-96. doi: 10.1016/j.csr.2015. 08.022

Boyce, J., Pozza, M., and Morris, B. (2001). High-resolution magnetic mapping of contaminated sediments in urbanized environments. Lead. Edge 20, 886-895. doi: 10.1190/1.14 87301

Boyce, J. I., Reinhardt, E. G., Raban, A., and Pozza, M. R. (2004). Marine magnetic survey of a submerged Roman harbour, Caesarea Maritima, Israel. Int. J. Naut. Archaeol. 33, 122-136. doi: 10.1111/j.1095-9270.2004.0 0010.x

Dehler, S. A., and Potter, D. P. (2002). Determination of nearshore geologic structure off western Cape Breton Island, Nova Scotia, using highresolution marine magnetics. Can. J. Earth Sci. 39, 1299-1312. doi: 10.1139/e 02-057

Demir, D., Bilim, F., Aydemir, A., and Ates, A. (2012). Modelling of Thrace Basin, NW Turkey using gravity and magnetic anomalies with control of seismic and borehole data. J. Pet. Sci. Eng. 86-87, 44-53. doi: 10.1016/j.petrol.2012. 03.013

Gomes, M. P., Vital, H., Stattegger, K., and Schwarzer, K. (2016). Bedrock control on the Assu Incised Valley morphology and sedimentation in the Brazilian Equatorial Shelf. Int. J. Sediment Res. 31, 181-193. doi: 10.1016/j.ijsrc.2015. 04.002

\section{FUNDING}

This research was part of the Fundação de Amparo a Pesquisa do Estado de São Paulo (FAPESP) grants 2016/24946-9 and 2011/22018-3 to LJ.

\section{ACKNOWLEDGMENTS}

The authors would like to thank SALT-Sea \& Limno Technology for the seismic acquisition system and IHS Markit for the Kingdom license. We also thank the Instituto Oceanográfico of Universidade de São Paulo for the research vessel used for the survey and the technicians who helped with the acquisition.

Heilbron, M., and Machado, N. (2003). Timing of terrane accretion in the Neoproterozoic-Eopaleozoic Ribeira orogen (SE Brazil). Precambr. Res. 125, 87-112. doi: 10.1016/S0301-9268(03)0 0082-2

Jobe, Z. R., Lowe, D. R., and Uchytil, S. J. (2011). Two fundamentally different types of submarine canyons along the continental margin of Equatorial Guinea. Mar. Pet. Geol. 28, 843-860. doi: 10.1016/j.marpetgeo.2010. 07.012

Kadima, E., Delvaux, D., Sebagenzi, S. N., Tack, L., and Kabeya, S. M. (2011). Structure and geological history of the Congo Basin: an integrated interpretation of gravity, magnetic and reflection seismic data. Basin Res. 23, 499-527. doi: 10.1111/j.1365-2117.2011.0 0500.x

Klein, D. A. (2005). Registros de variações ambientais no Canal de São Sebastião (Estado de São Paulo), durante o Último Ciclo Glacial. São Paulo: University of São Paulo.

Koša, E. (2015). Sea-level changes, shoreline journeys, and the seismic stratigraphy of Central Luconia, Miocene-present, offshore Sarawak, NW Borneo. Mar. Pet. Geol. 59, 35-55. doi: 10.1016/j.marpetgeo.2014. 07.005

Mahiques, M. M. (1995). Dinâmica sedimentar atual nas enseadas da região de Ubatuba, Estado de São Paulo. Bol. Inst. Ocean. 43, 111-122. doi: 10.1177/0013164474034 00221

Mahiques, M. M., and Souza, L. A. P. (1999). Shallow seismic reflectors and upper Quaternary sea level changes in the Ubatuba region, São Paulo State, Southeastern Brazil. Rev. Bras. Oceanogr. 47, 1-10. doi: 10.1590/S1413-773919990001 00001

Michel, G., Dupré, S., Baltzer, A., Ehrhold, A., Imbert, P., Pitel, M., et al. (2017). Pockmarks on the South Aquitaine Margin continental slope: the seabed expression of past fluid circulation and former bottom currents. Compt. Rendus Geosci. 349, 391-401. doi: 10.1016/j.crte.2017. 10.003

Miller, K. G., Sugarman, P. J., Browning, J. V., Sheridan, R. E., Kulhanek, D. K., Monteverde, D. H., et al. (2013). Pleistocene sequence stratigraphy of the shallow continental shelf, offshore New Jersey: Constraints of integrated ocean drilling program Leg 313 core holes. Geosphere 9, 74-95. doi: 10.1130/GES00795.1

Müller, R. D., Roest, W. R., Royer, J. Y., Gahagan, L. M., and Sclater, J. G. (1997). Digital isochrons of the world's ocean floor. J. Geophys. Res. Solid Earth 102, 3211-3214.

Suguio, K., and Martin, L. (1978). "Quaternary marine formations of the State of São Paulo and southern Rio de Janeiro," in 1978 International Symposium Coastal Evolution in the Quaternary, Special Publication no. 1 (São Paulo), 55.

Tessler, M. G. (1988). Dinâmica sedimentar quatemária no litoral sul paulista. São Paulo: University of São Paulo.

Veiga, F. A. (2005). Processos morfodinâmicos e sedimentológicos na plataforma continental rasa paranaense. Curitiba: Federal University of Paraná. 
Yoo, D. G., Chang, T. S., Lee, G. S., Kim, G. Y., Kim, S. P., and Park, S. C. (2016). Late Quaternary seismic stratigraphy in response to postglacial sea-level rise at the mid-eastern Yellow Sea. Quat. Int. 392, 125-136. doi: 10.1016/j.quaint.2015. 07.045

Yu, B., Liu, Y., Zhai, G., Bian, G., and Xiao, F. (2007). Magnetic detection method for seabed cable in marine engineering surveying. Geo. Spat. Inf. Sci. 10, 186-190. doi: 10.1007/s11806-007-0085-1

Zalán, P., and Oliveira, J. A. B. (2005). Origin and structural evolution of the Cenozoic Rift System of Southeastern Brasil [Origem e evolução estrutural do Sistema de Rittes Cenozóicos do Sudeste do Brasil]. Boletim Geociencias Petrobras 13, 269-300.
Conflict of Interest: The authors declare that the research was conducted in the absence of any commercial or financial relationships that could be construed as a potential conflict of interest.

Copyright (๑ 2020 Alves, Caldato, de Moura, dos Santos and Jovane. This is an open-access article distributed under the terms of the Creative Commons Attribution License (CC BY). The use, distribution or reproduction in other forums is permitted, provided the original author(s) and the copyright owner(s) are credited and that the original publication in this journal is cited, in accordance with accepted academic practice. No use, distribution or reproduction is permitted which does not comply with these terms. 